\title{
Decreased Cyclic AMP and Insulin Responses to Glucose in Pancreatic Islets of Diabetic Chinese Hamsters*
}

\author{
A. Rabinovitch, A. E. Renold and E. Cerasi** \\ Institute of Clinical Biochemistry, Department of Medicine, University of Geneva, Geneva, Switzerland
}

Summary. The dose as well as the time kinetics of insulin and adenosine-3',5'-monophosphate (cyclic AMP) responses to glucose were compared in pancreatic islets isolated from normal and diabetic Chinese hamsters. The insulin content in diabetic islets was about one-half that in normal islets. Insulin release in diabetic islets incubated for $10 \mathrm{~min}$ with glucose $60-1000 \mathrm{mg} / 100 \mathrm{ml}$ was from one-third to one-half that in normal islets. Glucose $1000 \mathrm{mg} / 100$ $\mathrm{ml}$ stimulated three-fold increases in insulin release without increasing the accumulation of $\left[{ }^{3} \mathrm{H}\right]$ cyclic AMP in either normal or diabetic islets prelabelled with $\left[{ }^{3} \mathrm{H}\right]$ adenine. However, in the presence of 1.0 $\mathrm{mM}$ of the phosphodiesterase inhibitor, 3-isobutyl-1methylxanthine (IBMX), glucose $150 \mathrm{mg} / 100 \mathrm{ml}$ elicited significant increases of insulin release $(+134 \%)$ and $\left[{ }^{3} \mathrm{H}\right]$ cyclic AMP accumulation in islets $(+44 \%)$ and incubation medium $(+48 \%)$ of islets of normal but not diabetic hamsters. Also, in perifusion experiments with $0.1 \mathrm{mM}$ IBMX, glucose $500 \mathrm{mg} / 100 \mathrm{ml}$ produced threefold greater increases in insulin release and two-fold greater increases in efflux of cyclic AMP in normal than diabetic islets. By contrast with the lesser effects of glucose in diabetic islets, $1.0 \mathrm{mM}$ IBMX increased islet and medium cyclic AMP, as well as insulin release, similarly in normal and diabetic islets. It is suggested that the impairment of glucoseinduced insulin release in islets of the diabetic Chinese hamster may be due to a defective interaction of glucose with the adenylate cyclase-cyclic AMP system in the pancreatic B cell.

\footnotetext{
* This work was presented in part at a meeting of the European Association for the Study of Diabetes, Sept. 1975, Munich, Germany

** Guest Professor at the University of Geneva, on leave from the Department of Endocrinology, Karolinska Hospital, Stockholm
}

Key words: Insulin release, diabetes, Chinese hamster, pancreatic islets, adenosine-3'5'-monophosphate (cyclic AMP).

In 1959, Yerganian and Meier [1] reported the occurrence of spontaneous diabetes mellitus among certain inbred sublines of Chinese hamsters. The syndrome is genetically determined, at least in part, and its spectrum ranges in severity from intermittent glucosuria to ketoacidosis. The diabetic Chinese hamster is considered a particularly useful model for the non-obese, insulin-deficient human diabetic [2]. Thus, diminished pancreatic insulin content [3-5], and impaired insulin responses to glucose [5-7] have been reported in these animals. On the basis of studies with the in vitro perfused pancreas of diabetic Chinese hamsters, Frankel et al. [8] have suggested that both A and $B$ cells of the diabetic pancreas may have a relatively specific impaired sensitivity to glucose. These authors found that theophylline both stimulated insulin release and increased glucose-stimulated insulin secretion similarly in normal and diabetic pancreata. These results are similar to those of Cerasi and Luft [9], who reported that the enhancing effects of theophylline on glucose-stimulated insulin release were intact in human subjects with decreased insulin responses to glucose. It appears, therefore, that the mechanism through which theophylline acts (presumably by elevating intracellular cyclic AMP) is intact, whereas the recognition of the glucose signal may be defective in diabetic hamsters [8] or man [10].

It is now widely accepted that glucose increases levels of adenosine-3',5'-monophosphate (cyclic AMP) in pancreatic islets of rats [11-13], and normal [14] as well as obese (ob/ob) mice [15]. However, the 
Table 1. Characteristics of Chinese hamsters used in this study ${ }^{a}$

\begin{tabular}{|c|c|c|c|c|c|c|c|}
\hline & Sex & $\begin{array}{l}\text { Age } \\
\text { months }\end{array}$ & $\begin{array}{l}\text { Body } \\
\text { weight } \\
\text { g }\end{array}$ & $\begin{array}{l}\text { Urine } \\
\text { glucose }^{\mathrm{b}} \\
0 \rightarrow 4+\end{array}$ & $\begin{array}{l}\text { Plasma } \\
\text { glucose } \\
\mathrm{mg} / 100 \mathrm{ml}\end{array}$ & $\begin{array}{l}\text { Plasma } \\
\text { insulin } \\
\mathrm{ng} / \mathrm{ml}\end{array}$ & $\begin{array}{l}\text { Islet } \\
\text { insulin }^{c} \\
\text { ng/islet }\end{array}$ \\
\hline Normals & $\begin{array}{l}q(16) \\
\sigma^{\prime}(20)\end{array}$ & $12-16$ & $29-48$ & $\begin{array}{l}0(32) \\
1+(3) \\
2+(1)\end{array}$ & $63-218$ & $0.35-3.50$ & \\
\hline Mean \pm SEM & & & $35.4 \pm 0.8$ & & $99 \pm 7$ & $1.35 \pm 0.13$ & $13.8 \pm 1.9(6)$ \\
\hline Diabetics & $\begin{array}{l}q(30) \\
\sigma^{\prime}(22)\end{array}$ & $12-16$ & $26-44$ & $\begin{array}{l}4+(46) \\
3+(1) \\
2+(2) \\
1+(3)\end{array}$ & $164-723$ & $0.05-4.85$ & \\
\hline Mean \pm SEM & $\mathrm{P}^{\mathrm{d}}$ & & $\begin{array}{l}34.3 \pm 0.8 \\
\mathrm{NS}\end{array}$ & & $\begin{array}{l}415 \pm 22 \\
<0.001\end{array}$ & $\begin{array}{l}0.92 \pm 0.15 \\
<0.05\end{array}$ & $\begin{array}{l}6.1 \pm 0.5(5) \\
<0.01\end{array}$ \\
\hline
\end{tabular}

role of cyclic AMP in insulin secretion is not clear. The aim of the present study was to determine whether impaired glucose-induced insulin release in islets of diabetic hamsters might be associated with reduced cyclic AMP responses to glucose.

\section{Materials and Methods}

\section{Animals (Table 1)}

Adult nonketotic diabetic Chinese hamsters (Cricetulus griseus) of both sexes, 12 to 16 months old, and weighing 26 to $44 \mathrm{~g}$, as well as age and weightmatched non-diabetic control hamsters obtained from the same colony, were kindly provided by Dr. K. Schulz (Dr. Karl Thomae GmbH, Biberach, W. Germany). At the time of sacrifice, in the fed state, 32 of the 36 "normal" hamsters had no glucosuria, and the others had $1+(3$ animals $)$ or $2+(1$ animal $)$ glucosuria; whereas 46 of the 52 diabetic hamsters had $4+$ glucosuria, and the others had $3+(1$ animal), $2+(2$ animals $)$ or $1+(3$ animals $)$ glucosuria. There was also some overlap of plasma glucose concentrations in the normal and diabetic hamsters; however, the mean plasma glucose concentration was clearly higher in the diabetic group $(415 \pm 22 \mathrm{mg} / 100$ $\mathrm{ml})$ than in the normals $(99 \pm 7 \mathrm{mg} / 100 \mathrm{ml})$. Also, the mean plasma insulin concentration was significantly lower in the diabetics $(0.92 \pm 0.15 \mathrm{ng} / \mathrm{ml})$ than in the normals $(1.35 \pm 0.13 \mathrm{ng} / \mathrm{ml})$. In the diabetic hamsters with high plasma insulin concentrations, the plasma insulin/glucose ratio was still considerably lower than in normal animals, indicating at least a relative, if not an absolute, deficiency of insulin secretion in the diabetic hamsters. The mean insulin content in islets of diabetic animals $(6.1 \pm 0.5 \mathrm{ng} /$ islet $)$ was about one-half of that in islets of normal hamsters (13.8 \pm $1.9 \mathrm{ng} /$ islet).

\section{Experimental Procedures}

Islets of Langerhans were isolated from normal and diabetic pancreata by digestion with collagenase [16]. Three or four pancreata were minced with scissors, and incubated at $37^{\circ} \mathrm{C}$ for 5 to $6 \mathrm{~min}$, with shaking, in $2 \mathrm{ml} \mathrm{Hank}$ 's solution equilibrated to $\mathrm{pH} 7.4$ with $95 \%$ $\mathrm{O}_{2}: 5 \% \mathrm{CO}_{2}$ and containing glucose $60 \mathrm{mg} / 100 \mathrm{ml}$ and $7 \mathrm{mg}$ collagenase (type $\mathrm{I}$, Worthington Chemical Corp., Freehold, N. J.). The average yield of islets was 100 from a normal hamster pancreas and 50 from a diabetic pancreas. The total batch of islets obtained from eight to twelve normal or diabetic hamsters was preincubated at $37^{\circ} \mathrm{C}$ for $60 \mathrm{~min}$ in $2.5 \mathrm{ml} \mathrm{Krebs}$ Ringer bicarbonate (KRB) buffer of the following composition (mM): $\mathrm{NaCl} 118.7, \mathrm{KCl} 4.75, \mathrm{CaCl} 2.54$, $\mathrm{KH}_{2} \mathrm{PO}_{4}$ 1.19, $\mathrm{MgSO}_{4}$ 1.19, $\mathrm{NaHCO}_{3} 24.64$, and equilibrated to $\mathrm{pH} 7.4$ with $95 \% \mathrm{O}_{2}: 5 \% \mathrm{CO}_{2}$. The buffer contained dialyzed bovine serum albumin 5 $\mathrm{mg} / \mathrm{ml}$, glucose $60 \mathrm{mg} / 100 \mathrm{ml}$, and $100 \mu \mathrm{Ci} / \mathrm{ml}$ $\left[{ }^{3} \mathrm{H}\right]$-2-adenine $(25 \mathrm{Ci} / \mathrm{mmol}$; New England Nuclear, Dreieichenhain, W. Germany) in order to label islet ATP [12]. The islets were then washed four times with $10 \mathrm{ml}$ of the radioactivity-free incubation buffer and transferred to a Petri dish at room temperature.

In the static incubation experiments, groups of 25 islets were incubated in a Dubnoff shaker at $37^{\circ} \mathrm{C}$, in $1.0 \mathrm{ml} \mathrm{KRB}$ buffer containing albumin $5 \mathrm{mg} / \mathrm{ml}$, and glucose $60,150,500$, or $1000 \mathrm{mg} / 100 \mathrm{ml}$, without and with $1.0 \mathrm{mM}$ of the phosphodiesterase inhibi- 
tor, 3-isobutyl-1-methylxanthine (IBMX, Aldrich Chemical Co., Milwaukee, Wis.). After 10 min of incubation, $0.1 \mathrm{ml}$ of medium was removed for insulin assay and $0.5 \mathrm{ml}$ for measuring the accumulation of $\left[{ }^{3} \mathrm{H}\right]$ cyclic AMP in the incubation medium. $100 \mu \mathrm{g}$ of unlabelled cyclic AMP was added to the remaining 0.4 $\mathrm{ml}$ of medium containing the islets, and this was boiled for $5 \mathrm{~min}$. The islet content of cyclic AMP was calculated as the difference between the $\left[{ }^{3} \mathrm{H}\right]$ cyclic AMP in the medium before and after boiling.

In the perifusion experiments, 100 islets were transferred into each of two chambers in parallel [17]. The basic medium was KRB buffer containing albu$\min 5 \mathrm{mg} / \mathrm{ml}$, glucose $60 \mathrm{mg} / 100 \mathrm{ml}$, and $0.1 \mathrm{mM}$ IBMX. The islets were perifused at a constant flow rate of 1.0 to $1.2 \mathrm{ml} / \mathrm{min}$, for an initial $30 \mathrm{~min}$ equilibration period with glucose $60 \mathrm{mg} / 100 \mathrm{ml}$, followed by a $30 \mathrm{~min}$ stimulation period with glucose 500 $\mathrm{mg} / 100 \mathrm{ml}$, then a return to glucose $60 \mathrm{mg} / 100 \mathrm{ml}$. The effluent from each chamber was collected in $5 \mathrm{~min}$ periods, using fraction collectors. Insulin output was calculated as the product of the insulin concentration in the effluent and the perifusion flow rate. Each $5 \mathrm{~min}$ output was used in entirety (except for $0.3 \mathrm{ml}$ for insulin assay) for the measurement of $\left[{ }^{3} \mathrm{H}\right]$ cyclic AMP efflux.

\section{Assays}

$\left[{ }^{3} \mathrm{H}\right]$ cyclic AMP was separated from other radioactive substances by ion exchange chromatography and barium sulphate precipitation [18]. Incubation media and boiled islet extracts, each containing $100 \mu \mathrm{g}$ of unlabelled cyclic AMP (as carrier) were adjusted to $1.0 \mathrm{ml}$ with water and put on to columns $(4 \times 0.6 \mathrm{~cm})$ of Dowex $50 \times 4,200-400$ mesh, $\mathrm{H}^{+}$form (Fluka, Buchs, Switzerland), and eluted with water. $300 \mu \mathrm{g}$ of carrier cyclic AMP was added to the 5 min outputs from the perifusion experiments, and these were adjusted to $6 \mathrm{ml}$ with water and divided on to three Dowex columns and eluted in parallel. Cyclic AMP was collected in the fifth and sixth $\mathrm{ml}$ fraction, and in the case of the perifusion samples, these fractions were pooled from the three parallel columns on which each sample had been placed. The eluates were further treated by $\mathrm{Ba} \mathrm{SO}_{4}$ precipitation of impurities, which were removed by centrifugation. Aliquots $(0.2$ $\mathrm{ml}$ ) of the supernatant were taken for determination of optical density (at $260 \mathrm{~nm}$ wave-length) of the carrier cyclic AMP, in order to correct for losses $(50-60 \%)$ of $\left[{ }^{3} \mathrm{H}\right]$ cyclic AMP during purification. The rest of the supernatant was counted in Instagel in a Beckman liquid scintillation counter. The eventual presence of radioactive impurities was controlled by subjecting islet incubates to (a) paper chromato- graphy, followed by (b) phosphodiesterase treatment, and (c) again paper chromatography, after which the spot coinciding with 5'-AMP was eluted and its radioactivity measured [19]. This method of purification yielded identical results as compared to the above described procedure, which was routinely used.

Insulin was measured with a charcoal separation method of radioimmunoassay [20] using a guinea pig antiporcine insulin antiserum kindly provided by Dr. P. H. Wright, Indiana University, Indianapolis, Ind. Monocomponent porcine insulin (kindly supplied by Dr. J. Schlichtkrull, NOVO Research Institute, Bagsvaerd, Denmark) was iodinated with ${ }^{125}$ iodine (Eidg. Institut für Reaktorforschung, Würenlingen, Switzerland), by the chloramine-T method [21], and purified on G 50 Sephadex (Pharmacia Fine Chemicals, Uppsala, Sweden). Purified porcine insulin (Novo Research Institute) was used as standard, since samples of islet extracts, islet incubates, and plasma from normal as well as diabetic Chinese hamsters diluted in parallel to porcine (or human) but not mouse or rat insulin standards. The insulin content of islets was measured by radioimmunoassay after extraction with acid-ethanol [22].

Plasma glucose was measured by a glucose oxidase method [23] using reagents kindly donated by Dr. F. Schmidt,Boehringer-Mannheim GmbH,W.Germany.

\section{Results}

\section{Dose-Response Studies with Glucose}

Figure 1 shows that insulin release in islets of diabetic hamsters was less than in islets of normal hamsters, at all concentrations of glucose from 60 to $1000 \mathrm{mg} / 100$ $\mathrm{ml}$, either without or with $1.0 \mathrm{mM}$ of the phosphodiesterase inhibitor, 3-isobutyl-1-methylxanthine (IBMX). Basal insulin release (with glucose 60 $\mathrm{mg} / 100 \mathrm{ml}$ ) in diabetic islets was about half that in normal islets (see also Fig. 3), and this was similar to the reduction of insulin content in diabetic islets (Table 1). Glucose $1000 \mathrm{mg} / 100 \mathrm{ml}$ elicited similar three-fold increases in insulin release in normal and diabetic islets. However, with 1.0 mM IBMX, glucose $1000 \mathrm{mg} / 100 \mathrm{ml}$ produced a five-fold increase in insulin release in normal islets and only a three-fold increase in diabetic islets. The threshold concentration of glucose required to increase insulin release was not determined in diabetic islets in the absence of IBMX, and in the presence of $1.0 \mathrm{mMIBMX}$ this was between glucose 150 and $500 \mathrm{mg} / 100 \mathrm{ml}$, i. e. higher than in normal islets (between 60 and $150 \mathrm{mg} / 100 \mathrm{ml}$ ). By contrast to the lesser effects of glucose in stimulating 


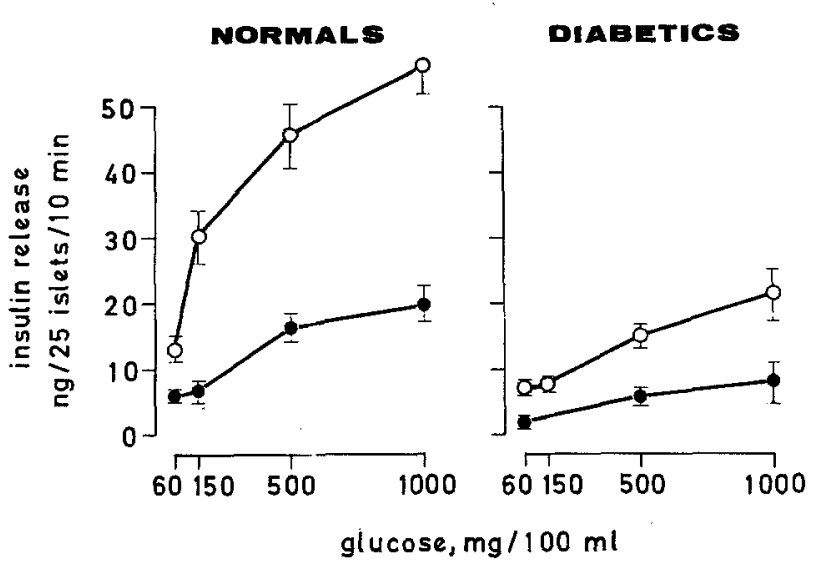

Fig. 1. Effects of glucose alone $(\bullet)$ and glucose plus $1.0 \mathrm{mM}$ 3-isobutyl-1-methylxanthine $(0)$, on insulin release in $10 \mathrm{~min}$ incubations of islets of normal and diabetic Chinese hamsters. Results are mean values \pm SEM of 7 incubations with normal islets ( 3 experiments) and 5 incubations with diabetic islets ( 3 experiments)

insulin release in diabetic islets, the phosphodiesterase inhibitor, IBMX, elicited similar absolute increases in insulin release (with glucose $60 \mathrm{mg} / 100 \mathrm{ml}$ ) as well as similar increases in glucose-induced insulin release in islets of normal and diabetic hamsters.

Figure 2 shows the accumulation of $\left[{ }^{3} \mathrm{H}\right]$ cyclic AMP in islets and incubation medium of islets of normal and diabetic hamsters in these dose-response studies with glucose. In the absence of IBMX, glucose did not produce any significant increase in the accumulation of $\left[{ }^{3} \mathrm{H}\right]$ cyclic AMP in islets or incubation medium of islets of either normal or diabetic hamsters. In the presence of $1.0 \mathrm{mM}$ IBMX, glucose 150 $\mathrm{mg} / 100 \mathrm{ml}$ elicited significant increases in the accumulation of $\left[{ }^{3} \mathrm{H}\right]$ cyclic AMP in islets $(+44 \%$, $\mathrm{p}<$ $0.05)$ and incubation medium $(+48 \%, p<0.02)$ of normal islets. Increasing the glucose concentration to $500 \mathrm{mg} / 100 \mathrm{ml}$ produced further increases of $\left[{ }^{3} \mathrm{H}\right]$ cyclic AMP in islets and incubation medium of normal islets; and with glucose $1000 \mathrm{mg} / 100 \mathrm{ml},\left[{ }^{3} \mathrm{H}\right]$ cyclic AMP was increased by $98 \%$ in islets $(\mathrm{p}<0.005)$ and $81 \%$ in medium $(\mathrm{p}<0.005)$ of normal islets. By contrast, $\left[{ }^{3} \mathrm{H}\right]$ cyclic AMP levels were not significantly increased in either islets or incubation medium of islets of diabetic hamsters, even with glucose 1000 $\mathrm{mg} / 100 \mathrm{ml}$. However, the phosphodiesterase inhibitor, IBMX $(1.0 \mathrm{mM})$ at the basal glucose concentration of $60 \mathrm{mg} / 100 \mathrm{ml}$, elicited similar increases (+ 200 to $300 \%$ ) in the accumulation of $\left[{ }^{3} \mathrm{H}\right]$ cyclic AMP

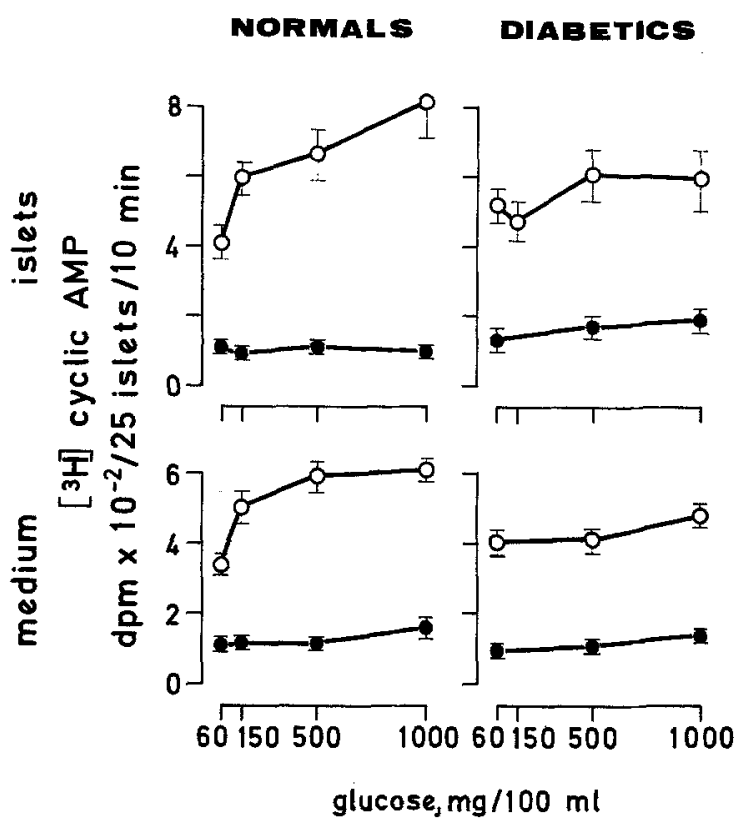

Fig. 2. Effects of glucose alone (•) and glucose plus $1.0 \mathrm{mM}$ 3 -isobutyl-1-methylxanthine (O), on the accumulation of $\left[{ }^{3} \mathrm{H}\right]$ cyclic AMP in islets (panels above) and incubation medium of islets (panels below) of normal and diabetic Chinese hamsters. Results are mean $\pm S E M$ for number of incubations indicated in Fig. 1

in islets and incubation medium of islets of normal and diabetic hamsters.

In summary, glucose was less effective in stimulating increases of either insulin release or cyclic AMP in islets of diabetic hamsters, at least in the presence of $1.0 \mathrm{mM}$ IBMX, whereas the phosphodiesterase inhibitor increased cyclic AMP and insulin release equally in normal and diabetic islets.

\section{Perifusion Experiments}

The time course of the insulin and cyclic AMP responses to glucose in the presence of a smaller concentration of IBMX $(0.1 \mathrm{mM})$ is shown in Figure 3. The presence of the phosphodiesterase inhibitor, as well as pooling of the perifusate over 5 min periods, was found necessary in order to detect the low concentration of $\left[{ }^{3} \mathrm{H}\right]$ cyclic AMP present in the effluent from the islets in these experiments. In contrast to the static incubation experiments with $1.0 \mathrm{mM}$ IBMX (Fig. 2), in these studies the islets of diabetic hamsters did demonstrate a small but significant $(+20-35 \%)$ cyclic AMP response to glucose. We have previously found that the effects of glucose on cyclic AMP levels in normal rat islets are greatest at a low concentration $(0.1 \mathrm{mM})$ of IBMX (unpublished).

Figure 3 shows that the time kinetics of insulin release, as well as $\left[{ }^{3} \mathrm{H}\right]$ cyclic AMP output, were similar in islets of normal and diabetic hamsters. However, 
the incremental outputs of insulin and $\left[{ }^{3} \mathrm{H}\right]$ cyclic AMP above basal levels measured during the last 5 min of the initial 30 min equilibration period with glucose $60 \mathrm{mg} / 100 \mathrm{ml}$, were significantly larger in normal than diabetic islets: the $30 \mathrm{~min}$ integrated incremental insulin output was $318 \pm 24 \mathrm{ng}$ in normal islets and $97 \pm 11 \mathrm{ng}$ in diabetic islets $(\mathrm{p}<0.001)$ and the corresponding $\left[{ }^{3} \mathrm{H}\right]$ cyclic AMP outputs were 619 $\pm 83 \mathrm{dpm}$ in normal islets and $273 \pm 32 \mathrm{dpm}$ in diabetic islets $(p<0.05)$.

\section{Discussion}

The present study with islets of normal and diabetic Chinese hamsters confirms the observations of decreased glucose-induced insulin secretion in diabetic animals in vivo [3] and in vitro [4,5]. Although abnormal islet morphology has been reported in diabetic hamsters [24] and the content of insulin was reduced by about $50 \%$ in diabetic islets in the present study (Table 1), these findings do not appear sufficient to explain all aspects of the impairment in insulin release. Thus, glucose increased insulin release less in diabetic than normal islets, whereas the phosphodiesterase inhibitor, IBMX, increased insulin release similarly in normal and diabetic islets (Fig. 1). Furthermore, the threshold for glucose-induced insulin release was clearly elevated in diabetic islets (at least in the presence of IBMX), thereby indicating a decreased sensitivity to glucose. The decreased capacity of the insulin response to glucose may be due, at least in part, to the reduced insulin content in diabetic islets. However, Frankel et al. [8] found that whereas the total pancreatic insulin content in diabetic hamsters was $35 \%$ of that in normals, there was no correlation between insulin release and stored insulin in either normal or diabetic animals.

In addition to the smaller effects of glucose on insulin release in diabetic islets, glucose also elicited smaller increases in cyclic AMP in diabetic than normal islets (Fig. 2). Thus, in the presence of $1.0 \mathrm{mM}$ IBMX, glucose $150 \mathrm{mg} / 100 \mathrm{ml}$ significantly increased cyclic AMP in normal islets, a maximal stimulation (two-fold increase) being observed with glucose 1000 $\mathrm{mg} / 100 \mathrm{ml}$. In contrast, there was no significant effect of any glucose concentration in diabetic islets in static incubations. Also, in perifusion experiments in the presence of $0.1 \mathrm{mM}$ IBMX (Fig. 3) glucose 500 $\mathrm{mg} / 100 \mathrm{ml}$ stimulated two to three-fold greater increases in the rates of cyclic AMP efflux in normal than diabetic islets. The efflux of cyclic AMP observed in the perifusion experiments probably reflects changes in islet levels of the nucleotide, since the effects of either glucose or IMBX on cyclic AMP

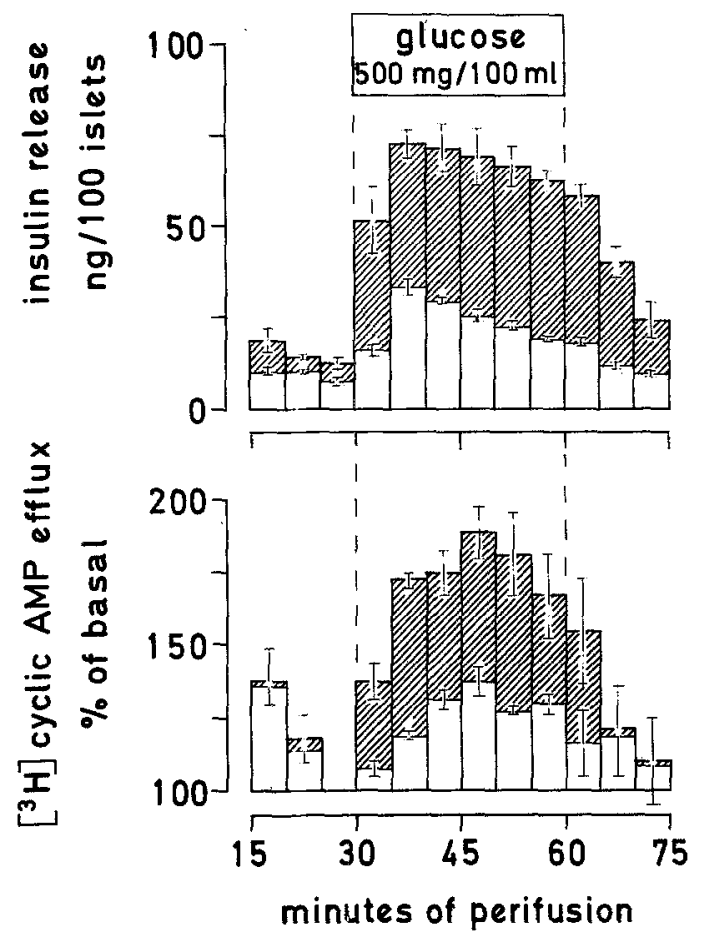

Fig. 3. Mean ( \pm SEM) rates of insulin release (panels above) and $\left[{ }^{3} \mathrm{H}\right]$ cyclic AMP efflux (panels below) in islets of normal hamsters (hatched + open portions of columns, 4 experiments) and diabetic hamsters (open portions of columns, 3 experiments) perifused with glucose $60 \mathrm{mg} / 100 \mathrm{ml}$ for $30 \mathrm{~min}$ (only last $15 \mathrm{~min}$ shown), followed by a $30 \mathrm{~min}$ period of stimulation with glucose $500 \mathrm{mg} / 100 \mathrm{ml}$, then a $15 \mathrm{~min}$ period with glucose $60 \mathrm{mg} / 100 \mathrm{ml}$. 3-isobutyl-1-methylxanthine $(0.1 \mathrm{mM})$ was present throughout. Efflux rates of $\left[{ }^{3} \mathrm{H}\right]$ cyclic AMP are expressed as percent of the mean output during the last $5 \mathrm{~min}$ of the initial $30 \mathrm{~min}$ perifusion with glucose $60 \mathrm{mg} / 100 \mathrm{ml}$ (basal output; $182 \pm 9 \mathrm{dpm}$ in normal islets and $218 \pm 17 \mathrm{dpm}$ in diabetic islets)

accumulation were similar in islets and medium of statically incubated islets (Fig. 2). In addition, we have observed strong correlations between the accumulation of cyclic AMP in islets and medium of islets incubated with different agents (unpublished data). It is also apparent in the perifusion experiments that early (0 to $10 \mathrm{~min}$ ) as well as later (10 to $30 \mathrm{~min}$ ) glucose-induced insulin release was reduced in diabetic islets, as has been reported in the perfused pancreas of the diabetic hamster [8]. Furthermore, the present study demonstrates that this was associated with both early and late reductions of the cyclic AMP responses to glucose.

The similarities between the dose as well as the time kinetics of glucose-stimulated insulin and cyclic AMP responses in islets of normal hamsters, together with the impairment of both responses in islets of diabetic animals, suggests a functional relationship between the effects of glucose on islet cyclic AMP 
levels and insulin release. However, the insulin responses to glucose in normal islets in the absence of IBMX, and in diabetic islets in the presence or absence of IBMX, were unassociated with any significant changes in islet or medium cyclic AMP during static incubations. Thus, it is evident that glucose may stimulate insulin release without necessarily increasing islet cyclic AMP, as has already been demonstrated $[11,15,25]$. Nevertheless, the present study demonstrates that the sensitivity as well as the capacity of the insulin response to glucose is reduced when the effects of the hexose on cyclic AMP are small or absent. Thus, in the presence of either $0.1 \mathrm{mM}$ or 1.0 mM IBMX, glucose was a less effective stimulator of insulin release and cyclic AMP formation in islets of diabetic than normal hamsters.

In the absence of the phosphodiesterase inhibitor, glucose did not increase cyclic AMP in either normal or diabetic islets, and it is interesting to note that this was associated with a high threshold (>150 mg/100 $\mathrm{ml}$ ) for glucose-induced insulin release in islets of the "normal" control hamsters. By contrast, insulin release is more sensitive to glucose in islets of normal rats and mice [26], and in these species, glucose (alone) increases islet levels of cyclic AMP [11-14]. We have also reported impaired insulin secretion associated with reduced cyclic AMP responses to glucose, in islets of neonatal rats [27] and rats starved for $48 \mathrm{~h}$ [28], as well as in islets of the spiny mouse (Acomys cahirinus), a rodent with deficient early phase insulin release and predisposition to spontaneous hyperglycaemia [29]. Also, Boquist et al. [30] reported considerably smaller insulin and cyclic AMP responses to $20 \mathrm{mM}$ glucose plus $1 \mathrm{mMIBMX}$ in islets of severely diabetic mice with a hereditary defect of insulin secretion (C57 BL/Ks J-db/db) than in their mildly hyperglycaemic controls (C57 BL/6 J-db $2 \mathrm{~J} /$ $\mathrm{db}^{2 J}$ ).

Kupiecki et al. [31] have rececently reported deficient insulin release in islets of Chinese hamsters with a diabetic genotype, but otherwise normal glucose tolerance, thereby suggesting that defective insulin release may be a primary defect in the diabetic $\mathrm{B}$ cell, presumably of genetic origin. These observations, together with the present findings of reduced insulin and cyclic AMP responses to glucose in islets of diabetic hamsters, support the proposal [10] that the impaired insulin release in diabetic human subjects is an early abnormality, possibly due to a defective interaction of glucose with the adenylate cyclase-cyclic AMP system in the B cell. Further studies with islets of "prediabetic" hamsters [31] may reveal whether this early deficit in insulin secretion is associated with impaired cyclic AMP metabolism.
Acknowledgements. We are grateful to Mrs. Liza Cavillier for her expert and devoted technical help. This work was supported by the Fonds National Suisse de la Recherche Scientifique (grants 3.384 .70 and 3.1060.73).

\section{References}

1. Yerganian, G., Meier, H.: Spontaneous hereditary diabetes mellitus in the Chinese hamster (Cricetulus griseus). Fed. Proc. 18, 514-518 (1959)

2. Renold, A. E., Burr, I.: The pathogenesis of diabetes mellitus. Possible usefulness of spontaneous hyperglycemic syndromes in animals. Calif. Med. 112, 23-24 (1970)

3. Dulin, W. E., Lund, G. H., Gerritsen, G. C.: Studies on diabetes in the Chinese hamster: [1] pancreatic and plasma insulin, [2] glucose metabolism by diaphragm and fat. Diabetes 15, 523-524 (1966)

4. Sims, E. A. H., Landau, B. R.: Diabetes mellitus in the Chinese hamster. I. Metabolic and morphologic studies. Diabetologia 3, 115-123 (1967)

5. Gerritsen, G. C., Dulin, W. E.: Characterization of diabetes in the Chinese hamster. Diabetologia 3, 74-84 (1967)

6. Malaisse, W., Malaisse-Lagae, F., Gerritsen, G. C., Dulin, W. E., Wright, P. H.: Insulin secretion in vitro by the pancreas of the Chinese hamster. Diabetologia 3, 109-114 (1967)

7. Chang, A. Y., Schneider, D. I.: Metabolic abnormalities in the pancreatic islets and livers of the diabetic Chinese hamster. Diabetologia 6, 180-185 (1970)

8. Frankel, B. J., Gerich, J. E., Hagura, R., Fanska, R. E., Gerritsen, G. C., Grodsky, G. M.: Abnormal secretion of insulin and glucagon by the in vitro perfused pancreas of the genetically diabetic Chinese hamster. J. clin. Invest. 53, 1637-1646 (1974)

9. Cerasi, E., Luft, R.: The effect of an adenosine-3',5'monophosphate diesterase inhibitor (Aminophylline) on the insulin response to glucose infusion in prediabetic and diabetic subjects. Horm. Metab. Res. 1, 162-168 (1969)

10. Cerasi, E., Luft, R.: Diabetes mellitus - a disorder of cellular information transmission? Horm. Metab. Res. 2, 246-249 (1970)

11. Charles, M. A., Fanska, R., Schmid, F. G., Forsham, P. A., Grodsky, G. M.: Adenosine-3',5'-monophosphate in pancreatic islets: Glucose-induced insulin release. Science 179, 569-571 (1973)

12. Grill, V., Cerasi, E.: Stimulation by D-glucose of cyclic adenosine-3',5'-monophosphate accumulation and insulin release in isolated pancreatic islets of the rat. J. biol. Chem. 249 , 4196-4201 (1974)

13. Zawalich, W. S., Karl, R. C., Ferrendelli, J. A., Matschinsky, F. M.: Factors governing glucose-induced elevation of cyclic $3^{\prime}: 5^{\prime}$ AMP levels in pancreatic islets. Diabetologia 11, 231-235 (1975)

14. Capito, K., Hedeskov, C. J.: The effect of starvation on phosphodiesterase activity and the content of adenosine $3^{\prime}: 5^{\prime}$-cyclic monophosphate in isolated mouse pancreatic islets. Biochem. J. 142, 653-658 (1974)

15. Hellman, B., Idahl, L.-A., Lernmark, A., Täljedal, I.-B.: The pancreatic beta cell recognition of insulin secretagogues: Does cyclic AMP mediate the effect of glucose? Proc. nat. Acad. Sci. (Wash.) 71, 3405-3409 (1974)

16. Moskalewski, S.: Isolation and culture of the islets of Langerhans of the guinea pig. Gen. comp. Endocr. 5, 342-353 (1965) 
17. Kikuchi, M., Rabinovitch, A., Blackard, W. G., Renold, A. E.: Perifusion of pancreas fragments: A system for the study of dynamic aspects of insulin secretion. Diabetes 23, 550-559 (1974)

18. Krishna, G., Weiss, B., Brodie, B. B.: A simple sensitive method for the assay of adenyl cyclase. J. Pharmacol. exp. Ther. 163, 379-385 (1968)

19. Grill, V.: Glucose-induced cyclic AMP accumulation in islets of Langerhans: Its relation to insulin release. Thesis, Stockholm: Karolinska Institute 1975

20. Herbert, V., Lau, K.-S., Gottlieb, C. W., Bleicher, S. J.: Coated-charcoal immunoassay of insulin. J. clin. Endocr. 25, 1375-1384 (1965)

21. Hunter, W. M., Greenwood, F. C.: Preparation of iodine-131 labelled human growth hormone of high specific activity. Nature (Lond.) 194, 495-496 (1962)

22. Scott, D. A., Fisher, A. M.: The insulin and zinc content of normal and diabetic pancreas. J. clin. Invest. 17, 725-728 (1938)

23. Bergmeyer, H. U., Bernt, E.: D-glucose-Bestimmung mit Glucose-Oxydase und Reoxydase. In: Methoden der Enzymatischen Analyse (Hrsg. H. U. Bergmeyer), S. 1172-1179. Weinheim: Verlag Chemie Weinheim 1970

24. Dulin, W. E., Gerritsen, G. C.: Summary of biochemical, physiological and morphological changes associated with diabetes in the Chinese hamster. Excerpta med. Int. Congr. Ser. 172, 806-812 (1969)

25. Cooper, R. H., Ashcroft, S. J. H., Randle, P. J.: Concentration of adenosine 3':5'-cyclic monophosphate in mouse pancreatic islets measured by a protein-binding radioassay. Biochem. $\mathrm{J}$. 134, 599-605 (1973)

26. Rabinovitch, A., Gutzeit, A., Kikuchi, M., Cerasi, E., Renold, A. E.: Defective early phase insulin release in perifused isolated pancreatic islets of spiny mice (Acomys cahirinus). Diabetologia 11, 457-465 (1975)

27. Grill, V., Asplund, K., Hellerström, C., Cerasi, E.: Decreased cyclic AMP and insulin response to glucose in isolated islets of neonatal rats. Diabetes 24, 746-752 (1975)

28. Rabinovitch, A., Grill, V., Renold, A. E., Cerasi, E.: The relationship of insulin release to glucose-induced cyclic AMP accumulation in pancreatic islets of fed and starved rats. J. clin. Invest. (in press)

29. Rabinovitch, A., Gutzeit, A., Grill, V., Kikuchi, M., Renold, A. E., Cerasi, E.: Defective insulin secretion in the spiny mouse (Acomys cahirinus), possible value in the study of the pathophysiology of diabetes. Israel J. med. Sci. 11, 730-737 (1975)

30. Boquist, L., Hellman, B., Lernmark, A., Täljedal, I.-B.: Content of adenosine $3^{\prime}: 5^{\prime}$-cyclic monophosphate in the pancreatic islets of mice with a hereditary defect of insulin secretion. Biochem. biophys. Res. Commun. 60, 1391-1396 (1974)

31. Kupiecki, F. P., Adams, L. D., Blanks, M. C., Gerritsen, G. C.: Insulin and glucagon release from perifused islets of Chinese hamsters that have a diabetic genotype but variable phenotype. Diabetes 24 (Suppl. 2), 409 (1975)

Received: April 24, 1976, and in revised form: July 27, 1976

Dr. A. Rabinovitch

Université de Genève

Institut de Biochimie Clinique

Sentier de la Roseraie

Ch-1211 Genève 4

Switzerland 